\title{
Toward a More Expansive Welfare Devolution Debate
}

\author{
Steven Schwinn \\ Introduction
}

In 1996, Congress enacted the Personal Responsibility and Work Opportunity

Reconciliation Act, ${ }^{1}$ or "PRWORA," more commonly known as federal "welfare reform." Congress designed the Act to address what it identified as several intractable problems in the welfare system: long-term dependency (and inter-generational dependency) on welfare benefits; out-of-wedlock pregnancies in the welfare population; and the lack of two-parent families. ${ }^{2}$ In order to address these issues, the Act included provisions to require recipients to participate in work activities as a condition of receipt of benefits, ${ }^{3}$ to limit the length of time that recipients may receive benefits, ${ }^{4}$ and to promote marriage. ${ }^{5}$

Although these provisions represented important and fundamental changes in the federal approach to welfare, there were even more dramatic changes in PRWORA: the Act eliminated the federal welfare entitlement for recipients, ${ }^{6}$ and devolved primary responsibility for welfare from the federal government to the states. ${ }^{7}$ The Act effected this devolution through the formation of a federal block-grant to the states, ${ }^{8}$ replacing the previous federal-state

\footnotetext{
${ }^{1}$ Pub. L. No. 104-193, 110 Stat. 2105 (codified as amended in scattered sections of 42 U.S.C.).

242 U.S.C. $\$ 601(\mathrm{a})(2)-(4)(2000)$.

342 U.S.C. $\$ 607(\mathrm{a})(1)(2000)$

${ }^{4} 42$ U.S.C. $\$ 608(\mathrm{a})(7)(2000)$.

542 U.S.C. $\$ 602$ (2000) (requiring states to "establish goals and take action to prevent and reduce the incidence of out-of-wedlock pregnancies" as part of their outline of a family assistance program required for eligibility for blockgrants).

${ }^{6} 42$ U.S.C. $\$ 601($ b) $(2000)$.

742 U.S.C. $\$ 603(\mathrm{a})(2000)$.

${ }^{8} \mathrm{Id}$.
} 
administrative and financing arrangement known as "cooperative federalism." of the federal entitlement in combination with devolution gave the states far greater latitude in designing, administering, and implementing their welfare programs. ${ }^{10}$

This devolution approach to welfare — a hallmark of what many call the "New Federalism"- -was driven largely by proponents' desire to increase state flexibility and experimentation in the welfare arena, allowing each state to tailor its program more precisely to local social, political, and economic conditions within that state. Opponents of devolution responded that devolution and the lack of federal standards, including the federal entitlement to benefits, would cause states to engage in a "race-to-the-bottom" as they design welfare programs to repel poor citizens (and thus avoid becoming "welfare magnets") and to attract and retain nonpoor (taxpaying) citizens. A debate about devolution in the welfare arena was thus framed around issues of state flexibility, experimentation, and jurisdictional competition. This debate raged in the legal literature, in the social science literature, in Congress and the states, and even in the courts (although, as described below, the Supreme Court in Saenz v. Roe ${ }^{11}$ effectively put an end to these debates in the courts). The welfare devolution debate continues to occupy space in the public discourse about welfare reform: it remains a prominent part of academic and policy evaluations of the original PRWORA and is reemerging in Congress as it considers variations of welfare devolution through reauthorization of PRWORA and as it debates devolution proposals for Food Stamps and Medicaid. The broader welfare devolution debate considered in this article cuts across welfare programs and expands from the original policy debates over the devolution in PRWORA to the current devolution debates in the context of reauthorization of PRWORA and

\footnotetext{
${ }^{9}$ See King v. Smith, 392 U.S. 309, 316 (1968) (coining the term "cooperative federalism" to refer to programs that are administered and funded jointly by the federal and state governments).

1042 U.S.C. $\$ 617$ (2000) ("No officer or employee of the Federal Government may regulate the conduct of States under this part or enforce any provision of this part, except to the extent expressly provided in this part.").

11526 U.S. 489 (1999).
} 
in the context of other current welfare reform proposals. This article considers all of these debates together —as the "welfare devolution debate"-and distinguishes between devolution debates on particular welfare programs only where such distinction is helpful to elucidate a rhetorical point in the debate.

The predominant rhetoric ${ }^{12}$ in the welfare devolution debate-experimentation and flexibility, state responsiveness to local needs, and "race-to-the-bottom" versus "race-to-thetop"- has an intuitive appeal. After all, we can easily imagine two hypothetical and contiguous states availing themselves of newfound flexibility and designing welfare programs to better meet the unique demands of their individual situations. And we can imagine that a policy that unleashes two programs (one for each state) - as opposed to a policy that protects a monopolistic single program (for the federation of the two states) — would seem to allow greater experimentation in the design of programs. We can imagine that these experiments, through trial-and-error and information sharing, should eventually result in better overall policy. We might also reasonably intuit that our two states, being closer to their citizens than the federation government, would be in a better situation to tailor individualized programs for their poor and to respond to the needs of all their citizens. Thus, pro-devolution arguments have some intuitive appeal on the basis of state flexibility and responsiveness to local needs.

But we can also easily imagine that these two hypothetical states would observe each other closely in designing their programs, because the states will reasonably anticipate that relatively generous programs will attract migrating poor from the other state, while relatively

\footnotetext{
${ }^{12}$ The other notable argument in the welfare devolution debate centers on the funding formula in the PRWORA. Because the PRWORA allocates funds to states through a blockgrant - as opposed to a cost-sharing formula under the AFDC program - states lose their incentive to spend their own funds on TANF programs and federal funds decline over time in real terms. Although the debate over the funding formula in PRWORA is certainly relevant for any discussion of federal-state relationships in the program, this debate tends to focus on the amount of federal money and incentives for states to spend funds on welfare programs, not which level of government is responsible for the design and implementation of those programs. The latter question is the focus of this article.
} 
stingy programs will repel them. The more generous state may therefore reasonably expect an influx of poor from its neighbor. We may reasonably intuit that each state will attempt to avoid attracting the poor (because they are perceived to be expensive, unappealing citizens) and that each state will therefore seek to provide benefits that are not relatively generous. Because the states observe each other in designing their programs, a competition will ensue, in which each states' welfare program exerts downward pressure on the welfare program of the other state until both states reach an equilibrium bottom - which is severely detrimental to the poor in both states. Thus, anti-devolution arguments have some intuitive appeal based on the notion that states will want to avoid becoming "welfare magnets" and therefore will engage in a "race-to-the-bottom."

The attractiveness and ubiquity of these intuitive arguments can be illustrated by the observation that they have essentially comprised the entire lexicon in the welfare devolution debate. These same arguments — or thinly veiled facsimiles — appear throughout the public discourse in academia, the popular press, policy institutions, and even the courts. Indeed, as described more fully below, ${ }^{13}$ it is difficult to find a public statement in the welfare devolution debate that does not somehow conform to the essential language and ideas of these arguments.

This is problematic, because while the arguments appear to represent polar positions on a uni-dimensional devolution spectrum, in fact these arguments represent variant positions in only a single dimension of a much more complicated, multi-dimensional spectrum. In other words, the lexicon of the devolution debate fails to account for other relevant principles in considering how to sort out federal-state relations in the design and delivery of welfare programs.

We can gain a window into the myopia of the debate by tracing these arguments to a common intellectual root, Charles Tiebout's famous 1956 article, A Pure Theory of Local

${ }^{13}$ See Part II: Neo-Tieboutian Rhetoric in the Debate on Welfare Reform, infra pp.16-29. 
Expenditures. ${ }^{14}$ Tiebout's singular contribution was to establish a market paradigm in the allocation of public goods, thus showing that public goods could be allocated in an economically optimal way, given certain rigid assumptions. ${ }^{15}$ Tiebout's market is comprised of local governments, each offering a unique tax-benefit package, coupled with full citizen mobility and knowledge, such that citizens "vote with their feet" and migrate to the jurisdiction that best satisfies their tax-benefit preferences. ${ }^{16}$ The model's central assumptions of local responsiveness and citizen mobility thus combine to achieve a market-like equilibrium in the provision of local public goods. ${ }^{17}$

Tiebout's original economic model evolved through subsequent scholars, social scientists, and policymakers into a model of "jurisdictional competition," in which local jurisdictions actively compete to attract certain citizens (and repel others) by adopting appealing (or distasteful) tax-benefit packages. Thus, jurisdictions use their flexibility to experiment with different policies in an attempt to satisfy citizen preferences, i.e., they "race to the top" by providing optimal tax-benefit packages for their citizens. But for some policies- those that benefit groups that the majority perceives to be a drag on state resources-jurisdictional competition theory predicts that states satisfy majority citizen preferences by repelling these presumably undesirable citizens by diminishing programs that benefit them. States thus act to avoid becoming "magnets" for these citizens by engaging in a "race-to-the-bottom" in policies that benefit them. The lexicon and ideas of the neo-Tieboutian jurisdictional competition model — and, even more narrowly, the specific assumption of full citizen mobility within that model — then, exactly match the lexicon and ideas of the devolution debate.

\footnotetext{
${ }_{15}^{14}$ Charles M. Tiebout, A Pure Theory of Local Expenditures, 64 J. PoL. ECON. 416 (1956).

15 See infra note 32 and accompanying text.

16 Tiebout, supra note 14 , at 418.

${ }^{17}$ Id. at 420 .
} 
Grounding the devolution debate exclusively in this neo-Tieboutian rhetoric results in an incomplete array of possibilities for federal-state relationships in providing welfare services. There are several endogenous reasons for this-reasons that grow out of flaws in the jurisdictional competition model itself, as it is applied to redistributional programs. ${ }^{18}$ First, welfare recipients occupy a unique place within a jurisdictional competition model: they are at the same time citizen-voters (with or without political power), direct recipients of (politically unpopular) government largesse, and mobile externalities of an economy or social system. Tiebout's model and its jurisdictional competition progeny do not fully account for these complex relationships between welfare recipients and the state. Second, jurisdictional competition does not account for varying bureaucratic competencies among governments and informational economies of scale within governments. For example, the model fails to properly account for the unique expertise of the federal government based upon its experiences with more than 50 state bureaucracies and welfare programs. Third, according to the vast (and increasing) social science literature, the most we can say about the rigid Tiebout assumptions is that we do not know if they are satisfied in the second-best real world. For example, the vast and increasing research on Tiebout's central assumption of citizen mobility has produced little conclusive evidence (either way) on whether welfare recipients actually migrate based on state welfare benefit levels, or, put another way, whether we actually observe the "opportunistic welfare migration" that we would expect in a first-best jurisdictional competition world.

It is not my primary intent here, however, to weigh-in in any serious way in the debate on the accuracy or usefulness of the jurisdictional competition model. Instead, I intend to comment

\footnotetext{
${ }^{18}$ For a thorough examination of problems with the jurisdictional competition model more generally, see William W. Bratton \& Joseph A. McCahery, The New Economics of Jurisdictional Competition: Devolutionary Federalism in a Second-Best World, 86 GEO. L. J. 201 (1997). For a similar critique from an economic perspective, see Truman F. Bewley, A Critique of Tiebout's Theory of Local Public Expenditures, 49 ECONOMETRICA 713 (1981).
} 
on the nature of the debate itself. I argue that we ought to expand the very parameters of the devolution debate to include other factors, some endogenous and some exogenous to the jurisdictional competition model but nevertheless relevant to federal-state relationships in welfare programs. ${ }^{19}$ Considerations of citizen knowledge and externalities are two principles endogenous to the model that may help us sort out appropriate governmental roles. Political participation, community values, and considerations of equality and justice are three principles exogenous to the model that may serve a sorting function. ${ }^{20}$ Looking beyond the limited spaces of economics, and considering citizens outside of their economic selves, we may discover new ideas for welfare federalism.

This paper first closely examines Tiebout's original hypothesis and the neo-Tieboutian theory of jurisdictional competition. Next, the paper attempts to ground the devolution debate in academia, the press, policy institutions, and the courts in a neo-Tieboutian framework. It argues that the devolution debate is rooted in neo-Tieboutian rhetoric.

The article then identifies some additional relevant considerations, or sorting principles, that have been absent from the debate. These principles help illustrate the myopia of the current debate and the resultant paucity of welfare federalism possibilities. The article suggests how an expanded debate, with an expanded array of principles, might result in a richer, more complex, and certainly different type of federal-state relationship in the design and delivery of welfare programs.

\footnotetext{
${ }^{19}$ Professor Steinzor has thoughtfully and forcefully made a similar argument in crafting "sorting principles" for federal-state relationships in the context of environmental regulation. See Rena I. Steinzor, Unfunded Environmental Mandates and the "New (New) Federalism": Devolution, Revolution, or Reform?, 81 MinN. L. REV. 97 (1996).

${ }^{20}$ See Robert E. GOOdIn, REASONS FOR WeLFARE (1988) (describing and critiquing justifications for welfare based on need, equality, and community). There are, of course, many other justifications for public welfare and redistributional programs, or even "theories of justice" more generally. It is not my goal to survey these here, except to note that from each of these we are likely to derive unique insights into the optimal allocation of responsibilities for welfare programs between federal and state governments. That we have not included these as considerations in the devolution debate - and that that omission has resulted in a myopic debate - is exactly the point here.
} 


\title{
Part I: Tiebout's Model and Jurisdictional Competition
}

Charles Tiebout's theory of jurisdictional competition provides a model for the way in which public goods are efficiently produced by various local public entities, or local

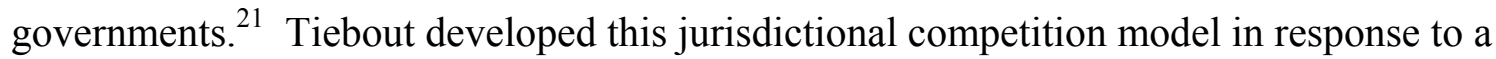
problem identified by Paul Samuelson ${ }^{22}$ and Richard Musgrave, ${ }^{23}$ among others, that no market solution existed to determine an efficient level of expenditures on public goods, when there is only one supplier of those goods, as in the case of the federal government. In other words, Samuelson and Musgrave concluded that public goods cannot be allocated with market efficiency in the absence of competition among multiple suppliers (or multiple public entities). This inefficiency manifests itself on both the supply side and the demand side. On the supply side, the lack of market competition results in overstated costs of public goods - the government pays too much for the services it provides. On the demand side, consumers - citizens - cannot accurately register their preferences for public goods in terms of the costs of public goods, because the costs are always overstated. Professors Bratton and McCahery summarize the Samuelson-Musgrave problem thus:

\begin{abstract}
According to the "Samuelson condition," public goods are allocated efficiently when the sum of a citizen's marginal rate of substitution of income for the good equals the marginal cost of an additional unit of the good. The Samuelson condition, however, is not easily met. With private goods, market competition exerts downward pressure on producers' marginal costs, and market prices provide concrete information about consumers' rates of substitution. With public goods, in contrast, no obvious market exerts downward pressure on government producers' marginal costs. Nor does an obvious mechanism force taxpaying citizen-consumers truthfully to reveal their rates of substitution. ${ }^{24}$
\end{abstract}

\footnotetext{
21 Tiebout, supra note 14.

22 Paul A. Samuelson, The Pure Theory of Public Expenditure, 36 REV. ECON. \& STAT. 387 (1954).

${ }^{23}$ Richard Abel Musgrave, The Voluntary Exchange Theory of Public Economy, 53 Q. J. EcON. 213 (1939).

24 Bratton \& McCahery, supra note 18, at 207 (footnotes omitted).
} 
As a result, according to Samuelson and Musgrave, the allocation of public goods is necessarily inefficient in the absence of market pressures. In the case of the federal government supplying uniquely federal goods, therefore, those goods cannot be provided with market efficiency.

Tiebout responded to this conclusion by examining the allocation of public goods on the local, not federal, level. He created a model in which multiple local governments compete as suppliers for taxpaying citizens in the market for local public goods. According to this model, each local government offers a unique tax-benefit package, and citizens "shop" for a jurisdiction that best matches their tax-benefit preferences. On the supply side, local governments compete to respond to citizen demand in the marketplace, exerting downward pressure on the marginal costs of public goods. On the demand side, fully informed and mobile citizens "vote with their feet ${ }^{\prime 25}$ and migrate to the jurisdiction that provides their desired public goods at a tax rate equal to (or less than) their marginal rate of substitution of income for the goods. ${ }^{26}$ Indeed, according to Tiebout, "[t]he act of moving or failing to move is crucial. Moving or failing to move replaces the usual market test of willingness to buy a good and reveals the consumer-voter's demand for public goods. ${ }^{27}$ According to the model, then, the equilibrium level of taxes and public goods that results in each jurisdiction will exactly match citizen preferences in each jurisdiction, achieving a market equilibrium in the provision of local public goods. ${ }^{28}$

\footnotetext{
${ }^{25}$ Tiebout does not use this term, but his theory does emphasize the importance — indeed, the centrality — of mobility in establishing a market for public goods:

Just as the consumer may be visualized as walking to a private market place to buy his goods, the prices of which are set, we place him in the position of walking to a community where the prices (taxes) of community services are set. Both trips take the consumer to market. There is no way in which the consumer can avoid revealing his preferences in a spatial economy. Spatial mobility provides the local public-goods counterpart to the private market's shopping trip.

Tiebout, supra note 14, at 422.

$26 \mathrm{Id}$.

${ }^{27}$ Id. at 420 .

${ }^{28} \mathrm{Id}$.
} 
Tiebout, in perhaps "one of the most-quoted paragraphs from one of the most-cited articles in urban politics[,]"29 summarized this theory as follows:

The consumer-voter may be viewed as picking that community which best satisfies his preference pattern for public goods. ... At the central level the preferences of the consumer-voter are given, and the government tries to adjust to the pattern of these preferences, whereas at the local level various governments have their revenue and expenditure patterns more or less set. Given these revenue and expenditure patterns, the consumer-voter moves to that community whose local government best satisfies his set of preferences. ${ }^{30}$

Tiebout's singular contribution was thus to create this market mechanism for the provision of local public goods, which ensures efficiency in the market for local public goods and overcomes the Samuelson-Musgrave problem. ${ }^{31}$

The model, of course, relies on several key assumptions:

1. Consumer-voters are fully mobile and will move to that community where their preference patterns, which are set, are best satisfied.

2. Consumer-voters are assumed to have full knowledge of differences among revenue and expenditure patterns and to react to these differences.

3. There are a large number of communities in which the consumer-voters may choose to live.

4. Restrictions due to employment opportunities are not considered. It may be assumed that all persons are living on dividend income.

5. The public services supplied exhibit no external economies or diseconomies between communities.

...

6. For every pattern of community services ... there is an optimal community size.

. .

7. ... [C]ommunities below the optimum size seek to attract new residents to lower average costs. Those above the optimum size do just the opposite. Those at an optimum try to keep their populations constant. ${ }^{32}$

\footnotetext{
${ }^{29}$ Keith Dowding et al., Tiebout: A Survey of the Empirical Literature, 31 URB. STUD. 767, 767 (1994).

30 Tiebout, supra note 14, at 418 (footnote omitted).

31 Samuelson, supra note 22, at 387-88.

32 Tiebout, supra note 14, at 419. For shorthand, I will refer to the first assumption as the "mobility assumption," the second assumption as the "knowledge assumption," the fourth assumption as the "employment assumption," the fifth assumption as the "economies assumption," and the sixth assumption as the "optimum size assumption."
} 
Three policy implications flow from this model. First, integration across jurisdictions "is justified [on economic welfare grounds] only if more of any service is forthcoming at the same total cost and without reduction of any other service."33 Although Tiebout is not specific about this, we would expect the reverse to hold, as well — that is, disintegration of services and devolution to various sub-jurisdictions also is justified on economic welfare grounds only if services increase or remain constant at the same total cost and without reduction of any other service. Tiebout offers a helpful example of police services-specifically, municipal versus local police_-but, under the model, this principle applies to any public service.

Second, policies that promote citizen mobility and dissemination of information-i.e., policies that advance a community toward the ideal of the mobility assumption and the knowledge assumption - enhance the economic efficiency in the allocation of public goods. ${ }^{34}$ Although Tiebout is not specific about this, we would expect, similarly, that policies that advance communities toward the ideal encompassed in any of the assumptions, ceteris paribus, would enhance the efficient allocation of public goods.

Finally, larger and dynamic communities may not be able to maintain a fixed revenueexpenditure pattern, as the model contemplates. ${ }^{35}$ Tiebout poses this issue as a normative one and fails to provide any extensive thoughts on it, but the implications are important for our purposes here.

Tiebout recognized some of the potential limitations of this model and qualified it accordingly. For example, Tiebout recognized that the economies assumption may not always hold, and that integration across local public entities may enhance the efficient allocation of public goods where disintegration results in diseconomies of scale (or where integration may

\footnotetext{
${ }^{33}$ Id. at 423.

${ }^{34} \mathrm{Id}$.

${ }^{35} \mathrm{Id}$.
} 
create economies of scale). ${ }^{36}$ If two communities—especially contiguous communities—can avoid diseconomies of scale (or can achieve economies of scale) by coordinating their public services in some way, they ought to do so. Tiebout also recognized that the mobility assumption and the knowledge assumption may not hold in the real world, and that we do not fully understand how people make decisions about where to live. ${ }^{37}$

Tiebout's economic model helped spawn the development of the neo-Tieboutian theory of "jurisdictional competition." The jurisdictional competition theory states that local jurisdictions - or states, as this theory seems to arise most often in the context of federalism debates, in which the central issue is state versus federal authority—actively compete with each other to retain and attract desirable, taxpaying citizens in the market for public goods. For most public goods, this competition has been described as a "race-to-the-top" among jurisdictions, as governments offer increasingly appealing packages of taxes and services to attract immigrants from other jurisdictions and to discourage the emigration of their own citizens. In a federalist system of government, in order to promote this competition among states and local jurisdictions - and thus to promote the economic efficiencies and optimal tax and service packages promised by the Tiebout model—the argument goes, we should devolve programs to the state and local level, granting these jurisdictions the flexibility and authority to compete, experiment, and respond to the needs of their citizens.

But for some public goods - most notably environmental regulation and social welfare programs such as Temporary Assistance for Needy Families (“TANF") and food stamps- the competition has been described as a "race-to-the-bottom," in which each jurisdiction competes to minimize the public good in order to attract certain citizens and repel others. In the much

\footnotetext{
${ }^{36} \mathrm{Id}$. at 423 .

${ }^{37}$ Id. at 423.
} 
discussed case of environmental regulation, the jurisdictional competition theory predicts that states will compete for desirable businesses at the expense of environmental protection and thus race to the bottom in the provision of environmental regulation. In the case of social welfare programs, the theory predicts that states will compete to repel economically, socially, and politically undesirable poor citizens by cutting relatively generous social welfare programs. States that provide relatively generous benefits, on the other hand, will encourage opportunistic welfare migration and become "welfare magnets" for the undesirable poor. The theory predicts that states will thus race to the bottom in the provision of social welfare benefits and programs, reducing those programs to a bare minimum or, in the extreme, eliminating them altogether. ${ }^{38}$

\footnotetext{
${ }^{38}$ At the most simple level, consider, for example, two jurisdictions, each with authority to tax and spend, each with an equal number of poor citizens, and each otherwise satisfying the Tiebout assumptions. Assume that jurisdiction A allocates an aggregate budget of $\$ 100$ to its welfare program, while jurisdiction B allocates only $\$ 50$, so that jurisdiction A provides twice the per capita welfare benefit to its poor citizens. According to the Tiebout hypothesis, we (and jurisdictions A and B) would expect welfare recipients to migrate from jurisdiction B to jurisdiction A until the per capita benefit in each jurisdiction is equal, i.e., until jurisdiction A has twice as many welfare recipients as jurisdiction B. In order to preempt this expected migration (or any expected migration) and the resulting drain on its resources, jurisdiction A will cut its welfare allocation to remove any incentive to migrate. Thus, jurisdiction A will reduce its welfare allocation to $\$ 50$, so that its per capita spending is equal to jurisdiction $\mathrm{B}$. (The jurisdictions may continue to reduce their welfare allocations in a competition to encourage the emigration of their own poor citizens.) The jurisdictions will continue to react to each other in a "race-to-the-bottom" until they reach an equilibrium level of welfare spending in both jurisdictions of $\$ 50$ (or less, if the jurisdictions continue to compete to encourage welfare emigration). This equilibrium represents (at most) the lowest level of welfare spending between the jurisdictions

Alternatively, consider the same two jurisdictions, but assume that jurisdiction A provides recipients with $\$ 100$ per month for the first three years and $\$ 50$ per month for the next two years. Jurisdiction B, in contrast, provides each recipient with $\$ 75$ per month for five years. According to the Tiebout hypothesis, we (and jurisdictions $\mathrm{A}$ and $\mathrm{B}$ ) would expect a rational welfare recipient may choose to reside in jurisdiction $\mathrm{A}$ for three years and then to move to jurisdiction B for two years in order to maximize benefits between the two jurisdictions. In order to preempt the anticipated migration, jurisdiction B will reduce its benefits during the final two years of eligibility to $\$ 50$. In response, jurisdiction A will reduce its own benefits during the first three years to $\$ 75$ in order to prevent migration during those years. (The jurisdictions may continue to reduce their welfare benefits in a competition to encourage the emigration of their own poor citizens.) At the close of this "race-to-the-bottom," the resulting equilibrium level of welfare benefits in both jurisdictions will be $\$ 75$ for the first three years and $\$ 50$ for the final three years (or less, if the jurisdictions continue to compete to encourage welfare emigration). Just like the equilibrium in the first example, the equilibrium in this example is, at most, the lowest level of benefits offered by each jurisdiction at the beginning of the competition.

We may observe these phenomena outside the arena of cash benefits, as well. For example, we can easily imagine that states might similarly race to the bottom by implementing more stringent requirements for program participation —e.g., more stringent work requirements or collateral program requirements — or more challenging administrative hurdles to gaining or retaining benefits-e.g., application requirements, reporting requirements, etc.
} 
In contemporary federalism debates, we increasingly hear the rhetoric of the neoTieboutian jurisdictional competition theory to justify or oppose devolution of authority from the federal government to the states. ${ }^{39}$ Proponents of devolution thus employ concepts and arguments related to local flexibility, experimentation, and competition among jurisdictions in the market for public goods. Market-like efficiency in the provision of public goods, they say, can only come through local competition, and competition can only be achieved by providing states increased flexibility and the ability to experiment-i.e., the ability to craft their own unique tax-benefit packages to retain and attract citizens that are desirable to them. In our federal system, this means devolution of authority to the states.

Similarly, opponents of devolution use concepts and arguments related to the "race-tothe-bottom" and "welfare magnets," implying that jurisdictional competition results in an artificial decrease in certain public goods, as states and local jurisdictions compete to attract desirable citizens (such as corporations, in the case of environmental regulation goods) and to repel undesirable others (such as the poor, in the case of social welfare benefits). To opponents, only integration of goods at the federal level (in the form of federal standards or federal entitlements, for example) will ensure that states do not reduce certain public goods to an

For a more sophisticated, mathematical model of the race to the bottom, see JAN K. BRUECKNER, WELFARE REForm AND InTERSTATE Welfare COMPETITION: THeORY AND Evidence 7-12 (Urban Inst. 1998), available at http://www.urban.org/url.cfm?ID=307786.

${ }^{39}$ Neo-Tieboutian rhetoric is not limited to the welfare devolution debate. For example, commenting on broader federalism debates, outside the welfare arena, Professor Pettys wrote the following:

In their quest to comprehend federalism, jurists have devoted considerable attention to the benefits that may be achieved when state and local governments compete with one another for a mobile citizenry. Prompted in part by Charles Tiebout's famous 1956 article, many have wedded themselves to the view that horizontal competition among states and localities helps to ensure that citizens will have an array of governmental options from which to choose and that governments will have a marketlike incentive to satisfy citizens' demands in increasingly efficient ways. This argument finds a close cousin in the frequent observation that states and localities serve as laboratories for testing social and economic programs.

Todd E. Pettys, Competing for the People's Affection: Federalism's Forgotten Marketplace, 56 VAnd. L. Rev. 329, 331-32 (2003) (citations omitted). 
unsustainably low level as a result of this competition among jurisdictions. In our federal system, this means the retention of standards and authority at the federal level.

But while these apparently polar positions result in two different conclusions about the merits of devolution, they derive from the same neo-Tieboutian jurisdictional competition theory and its assumptions. The next section explores these positions in the context of the federalism debate over welfare reform.

\section{Part II: Neo-Tieboutian Rhetoric in the Debate on Welfare Reform}

For much of the recent history of our social welfare system, federal-state relationships in the delivery of social welfare programs are best described in terms of some form of cooperative federalism. For our purposes, there are three hallmarks of this arrangement. First, the federal government sets certain standards for the states — rules with which states must comply in providing benefits to families - and entitlements for recipients. ${ }^{40}$ The focus of the regulations is on who qualifies for benefits, based largely on income, and the technical parameters within which states must work to provide those benefits. The regulations act to protect recipients and ensure their federal entitlement within the state program. Second, funding is based on a shared formula, in which the level of federal funding is a function of individual state need. The federal share of the total formula is a multiple of state expenditures, thus providing an incentive for states to spend more, not less, on their programs. Finally, states have some flexibility to tailor certain limited elements of their programs, such as individual standards of need for recipients.

\footnotetext{
${ }^{40}$ See David A. Super, Offering an Invisible Hand: The Rise of the Personal Choice Model for Rationing Public Benefits, 113 YALE L. J. 815, 819-20 (2004) (stating that the period between the 1960s and 1995 was a "legalistic era" in public benefits law, the guiding principle of which was "constraining discretion through uniform [federal] rules").
} 
This flexibility derives from the reality that standards of need may vary from location to location, and that states are in a better position than the federal government to assess needs.

This form of cooperative federalism came to an end - in the Aid to Families of Dependent Children (“AFDC") program, at least—in 1996, when Congress enacted the PRWORA. ${ }^{41}$ The PRWORA replaced cooperative federalism with devolution, with three hallmarks that correspond to the hallmarks of cooperative federalism. First, the PRWORA changed the nature of federal standards from a focus on benefits to a focus on work. The PRWORA thus regulates the nature of recipients' work and states' work participation rates and eliminates federal protections for the receipt of benefits-including the individual entitlement for benefits. Second, the PRWORA changed the funding mechanism by replacing the cooperative funding formula — which encourages states to increase funding — to a fixed block-grant—which encourages states to decrease funding. Finally, the PRWORA provides states with greater flexibility to tailor their own individual programs, within the parameters of the very broad goals of the PRWORA and the more specific federal work participation rates.

The shift from cooperative federalism to devolution in the AFDC and TANF programsand in welfare programs more generally, such as Food Stamps and Medicaid-is ensconced in a public discourse that draws almost exclusively on neo-Tieboutian rhetoric and the language of interstate jurisdictional competition, particularly as they relate to Tiebout's mobility assumption. Indeed, it is difficult to find rhetoric, arguments, or analysis in the public record of the devolution debate that is rooted in anything but the mobility assumption within the neoTieboutian lexicon. The pro-devolution side of the debate is framed in terms of "flexibility," "experimentation," "responsiveness to local (state) needs," and "race-to-the-top," while the antidevolution side of the debate is framed in terms of "welfare magnets," and "race-to-the-bottom."

${ }^{41}$ Pub. L. No. 104-193, 110 Stat. 2105 (codified as amended in scattered sections of 42 U.S.C.). 
This section traces this rhetoric through the welfare devolution debates, discourse, and analyses in academia, policy institutions, and the press, and the devolution debates in Congress, the states, and the courts. It is worth reminding the reader that "welfare devolution debates" or "devolution debates" as used here do not refer exclusively to the devolution debates surrounding the original PRWORA; rather, I use those terms to include the devolution debates with respect to AFDC/TANF, Food Stamps, and Medicaid in the original welfare reform bills, with respect to these programs in the reauthorization legislation, and with respect to welfare programs generally.

An analysis by Professors Buckley and Brinig well represents the rhetoric on the prodevolution side of the debate in academia:

\section{Many of the standard arguments for assigning powers to the state level} apply in the case of welfare responsibilities. Devolution of welfare powers usefully reduces information costs, promotes experimentation, and permits people to sort themselves out by policy preferences through migration.

Had there been a race to the bottom, states would have reacted to increased welfare pressure with welfare cuts. We find no evidence that this happened. ${ }^{42}$

The anti-devolution side of the debate in academia has featured perhaps even stronger neo-Tieboutian rhetoric and analysis. This side of the debate seems to recognize some of the benefits of local flexibility in welfare delivery systems, but it is concerned about a race to the bottom among independently operating states, based on jurisdictional competition assumptions, most notably the mobility assumption. This side of the debate, therefore, tends to focus on the phenomenon of opportunistic welfare migration.

Paul Peterson is an eloquent and thoughtful leader on this side of the debate. In The Price of Federalism, Peterson predicts a race to the bottom ${ }^{43}$ and welfare magnets ${ }^{44}$ based on data that

\footnotetext{
${ }^{42}$ F.H. Buckley \& Margaret F. Brinig, Welfare Magnets: The Race for the Top, 5 Sup. CT. ECon. Rev. 141, 142-44 (1997).

${ }^{43}$ Paul E. Peterson, The Price of Federalism 126 (1995).

${ }^{44}$ Id. at 123.
} 
indicate that after 1969 the poor considered welfare benefits in making residential choices-i.e., that opportunistic welfare migration exists — and that states actively and rationally adjust their welfare programs to avoid an influx of the poor. ${ }^{45}$ Peterson and Marc C. Rom's book Welfare Magnets: A New Case for a National Standard is devoted almost entirely to issues of opportunistic welfare migration and, as the title suggests, the magnetic effects of state welfare programs. ${ }^{46}$

\section{David Ellwood of the John F. Kennedy School of Government at Harvard University} testified before the Senate Finance Committee in 1996 on welfare reform:

I am fearful that the current round of reform proposals are more likely to simply reduce benefits and cut people off than move people from welfare to work. The danger of a race to the bottom is very real.

....

Some states may find it much easier to move people from welfare to the state border than from welfare to work. And so the race to the bottom may begin. ${ }^{47}$

\footnotetext{
${ }^{45}$ Id. The journal Publius ran an excellent series of articles on welfare devolution in its Summer 1998 edition. These articles invariably turn to neo-Tieboutian language and analyses in examining issues of welfare devolution. Richard M. Francis, Predictions, Patterns, and Policymaking: A Regional Study of Devolution, PuBLIUs, Summer 1998, at 143 (examining the response of state officials under welfare devolution, in light of the opposing forecasts of "race to the bottom" and local support for the poor); Samuel H. Beer, Welfare Reform: Revolution or Retrenchment, Publius, Summer 1998, at 9, 12 ("If there is a race to the bottom, that surely spells retrenchment. The possibility is inherent in the United States federal system. Thanks to its dispersion of authority among the states, American federalism gives rise to that familiar problem of collective action in which competition among separate actors tempts them individually to do what they otherwise prefer not to do."); Scott W. Allard, Revisiting Shapiro: Welfare Magnets and State Residency Requirements in the 1990s, PubliUS, Summer 1998, at 45 (reviewing the evidence on opportunistic welfare migration in the context of welfare residency requirements); Sanford F. Schram \& Joe Soss, Making Something Out of Nothing: Welfare Reform and a New Race to the Bottom, PuBlius, Summer 1998, at 67 (critically examining the "laboratories of democracy," "welfare magnet," and "race to the bottom," theses); Irene Lurie, Watching the Race: Where You Sit Affects What You See, Publius, Summer 1998, at 89 (questioning the "race to the bottom" and "welfare magnet" theses); Jocelyn M. Johnston \& Kara Lindaman, Implementing Welfare Reform in Kansas: Moving, but not Racing, Publius, Summer 1998, at 123 (examining the "race to the bottom" theses in the context of Kansas's welfare program); Mark Carl Rom, Paul E. Peterson, \& Kenneth F. Scheve, Jr., Interstate Competition and Welfare Policy, PuBlius, Summer 1998, at 17 (examining welfare devolution and interstate competition).

${ }^{46}$ Paul E. Peterson \& Mark C. Rom, Welfare Magnets: A New Case for a National Standard (1990). But see Sanford Schram, et al., Without Cause or Effect: Reconsidering Welfare Migration as a Policy Problem, 42 AM. J. PoL. SCI. 210 (1998).

${ }^{47}$ Welfare and Medicaid Reform: Hearing on S. 1795 Before the Senate Comm. on Finance, 104th Cong. 114-15 (1996) (statement of David T. Ellwood, John F. Kennedy School of Government, Harvard University). See also R. Kent Weaver, ENDing Welfare As We Know It 27-28 (2000) (“State discretion in administering the program may also lead to competition among states to keep benefits low to avoid becoming a 'welfare magnet,' attracting
} 
Other empirical and policy analyses have been less conclusive, but they nevertheless are couched in neo-Tieboutian terms, examining neo-Tieboutian assumptions. ${ }^{48}$ A variety of empirical studies from academics and policy think-tanks have examined interstate jurisdictional competition in welfare programs ${ }^{49}$ and, particularly, opportunistic welfare migration. ${ }^{50}$

In the law and policy literature, commentators have similarly conformed their analyses of welfare devolution to the neo-Tieboutian lexicon. For example, one commentator concluded firmly that welfare devolution would result in a race to the bottom. ${ }^{51}$ Another concluded that opportunistic welfare migration is more myth than reality, ${ }^{52}$ but that states nevertheless react to changing poverty rates — even if not driven by opportunistic welfare migration-in designing welfare programs. ${ }^{53}$ Yet other commentators have used neo-Tieboutian rhetoric to describe and analyze particular aspects of the welfare devolution debate. ${ }^{54}$

\footnotetext{
'undesirable' beneficiaries from other states. In fact, a race to the bottom may occur even if welfare magnet effects are weak as long as politicians believe that they are real.”) (citing PETERSON \& ROM, supra note 46).

${ }^{48}$ For a more general overview of empirical studies of Tietoutian phenomenon, see Dowding et al., supra note 29.

49 See, e.g., Brueckner, supra note 38; Elizabeth T. Powers, Block Granting Welfare: Fiscal Impact on the STATES (Urban Inst. 1999), available at http:/www.urban.org/ElizabethTPowers; JAN K. BRUECKNER, WELFARE ReForm And the RACE TO THE Bottom: Theory And Evidence (Inst. Gov’t \& Pub. Aff. Working Paper \#64 1998), available at http://www.igpa.uiuc.edu/publications/workingPapers.htm; David N. Figlio et al., Do States Play Welfare Games?, 46 J. URB. Econ. 437 (1999); L. SAAVEDRA, A Model of Welfare COMPETITION With EVIDENCE FROM AFDC (Inst. Gov’t \& Pub. Aff. Working Paper \#64 1998), available at http://www.igpa.uiuc.edu/publications/workingPapers.htm; JAMES FosSETT \& THOMAS GAIS, A NEw PUZZLE FOR Federalism: DifFerent StAte Responses to Medicaid And Food StAmps (2002), available at http://www.rockinst.org/publications/welfare_and_jobs.html.

${ }^{50}$ For a good overview of the several empirical studies of neo-Tieboutian assumptions in the welfare context, see Brueckner, supra note 38, at 13-17.

${ }^{51}$ See Note, Devolving Welfare Programs to the States: A Public Choice Perspective, 109 HARV. L. REv. 1984, 1986-87 (1996) ("Devolution - in combination with the constitutionalized 'right to travel' - will produce economic pressure for states to implement welfare programs that are less generous than those they would have implemented in the absence of devolution: 'Fearful that they will become a Mecca for the poor if their welfare programs are more generous than those of their neighbors, states will compete in their stinginess."') (citations omitted).

52 See generally Shauhin A. Talesh, Note, Welfare Migration to Capture Higher Benefits: Fact or Fiction?, 32 Conn. L. REV. 675, 676, 698 (2000).

${ }^{53} \mathrm{Id}$. at 698 ("“In other words, states may in fact be influenced by changing poverty rates in deciding benefit levels, even if there is not much welfare migration in or out of the state."') (quoting Sanford Schram, et al., supra note 46, at 215; analyzing Peterson and Rom's work).

${ }^{54}$ See, e.g., Nan S. Ellis \& Cheryl M. Miller, Welfare Waiting Periods: A Public Policy Analysis of Saenz v. Roe, 11 STAN. L. \& POL'Y REV. 343, 344 (2000) (describing durational residency requirements under state welfare reform programs as efforts to diminish opportunistic welfare migration); Joshua D. Sarnoff, Cooperative Federalism, the Delegation of Federal Power, and the Constitution, 39 ARIZ. L. REV. 205, 210 (1997) (“Congress delegates power
} 
Similar themes echo in the popular press. Robert Reischauer, in the Washington Post, outlined the two sides of the debate nicely:

To the states, block grants hold out the promise of reduced federal regulation and a chance to use Washington's money to pay for state-designed programs that may be better tailored to local values and conditions.

[But] [f]earful that they will become a Mecca for the poor if their welfare programs are more generous than those of their neighbors, states will compete in their stinginess. ${ }^{55}$

\section{A 2004 editorial by the Chicago Tribune editorial board is typical of the rhetoric on the}

pro-devolution side of the debate:

Welfare reform has been successful precisely because it recognized that the federal government should get the heck out of the way and let states figure out how best to end the culture of welfare dependency.

The law set limits on how long families could receive welfare. But it also gave chunks of money to the states and broad discretion over how to prepare people for the world of work.

And so, 50 experiments were born.

Flexibility has been the hallmark of welfare reform. States are perfectly capable of learning from each others' successes - and failures - thank you. ${ }^{56}$

\section{Syndicated columnist Matthew Miller well represents the rhetoric on the anti-devolution}

side of the debate - a rhetoric that amounts to the neo-Tieboutian mirror-image of the prodevolution rhetoric:

to the states, moreover, in order to satisfy preferences for state-level regulation and for state citizens' values.") (citing Harold J. Krent, Fragmenting the Unitary Executive: Congressional Delegations of Administrative Authority Outside the Federal Government, 85 Nw. U. L. REv. 62, 76 (1990)); Jon Michaels, Deforming Welfare: How the Dominant Narratives of Devolution and Privitization Subverted Federal Welfare Reform, 34 SETON HALL L. REV. 573, 583 (2004) (“Advocates for greater states' rights and/or greater privatization gained considerable momentum at the same time these welfare critics were demanding substantive reform. These 'smaller government' advocates championed wholesale devolution and deregulation in the name of greater democracy, authenticity, choice, and efficiency ....").

${ }^{55}$ Robert D. Reischauer, The Blockbuster Inside the Republicans' Budget; In the Rush to Fiscal Devolution, Has Anyone Figured Out How to Divvy Up the Cash?, Washington Post, May 14, 1995, at C2. See also David S. Broder, Race to the Bottom?, WASHINGTON POST, Aug. 6, 1995, at C9 ("Welfare programs could be tailored more easily to local circumstances [with devolution] .... The critics' fear is that instead of innovating, the states will engage in a 'race to the bottom' that shreds the social safety net.").

56 Will Congress Kill Welfare Reform?, CHI. TRIB., July 11, 2004, at C10. See also Douglas J. Besharov, There's More Welfare to Reform, N.Y. TIMES, Mar. 6, 2004, at A2 (arguing for greater flexibility for the states in meeting certain work participation rates); Editorial, Race to the Top, WALL ST. J., April 2, 2004, at A8. 
Without [a federal matching fund] incentive, states will unleash a competitive frenzy of benefit cuts, fueled by their understandable desire to be stingier than their neighbors to avoid attracting new dependants.

Federal standards and dollars assure the neediest won't be sacrificed in such a "race to the bottom."

Because the devolution debate in academia, policy think-tanks, and the popular press is so firmly rooted in neo-Tieboutian rhetoric, it should come as no surprise that the rhetoric of Congress and other policy makers in the devolution debate is similarly—but perhaps even more myopically - neo-Tieboutian in nature. The following statements by members of the House Commerce Committee during testimony on welfare reform in 1996 well represent the polar positions in the devolution debate on Medicaid:

Rep. Eliot Engel (D-NY): The state of New York is very generous in terms of health care. .... It's kind of what I'd like to call a race to the bottom, because many residents, who live in states who don't cover them, will go to states that will cover them, burdening these states, like New York, even further.

Rep. Scott L. Klug (R-WI) [question to a witness]: And rather than seeing this as a race to the bottom, would it be your argument that what you see has given states better flexibility - may have a race to the top? That essentially, Wisconsin, Michigan, Virginia, Florida, could all create programs that are much more effective and much cheaper to operate than what the federal government does? ${ }^{58}$

State flexibility was a key component of the original PRWORA, ${ }^{59}$ and the rhetoric in

Congress and the states reflected that. But in the wake of PRWORA-as Congress evaluates welfare devolution and debates reauthorization—neo-Tieboutian rhetoric often reads like an

\footnotetext{
${ }^{57}$ Matthew Miller, Editorial, States Would Shred the Safety Net, Rocky MounTAIN NEWS, March 10, 1996, at 58A.

${ }^{58}$ Hearing of the House Commerce Committee on Welfare Revision, Jun 11, 1996. See also President William J. Clinton, Remarks by the President on Welfare Reform at the White House (Aug. 4, 1998) ("Two years ago we said welfare reform would spark a race to independence, not a race to the bottom, and this prediction is coming true."), available at http://clinton4.nara.gov/WH/New/html/19980804-4271.html.

59 See H.R. Conf. REP. 104-725, at 262 (July 20, 1996), reprinted in 1996 U.S.C.C.A.N. 2649, 2650 (Joint Explanatory Statement of the Committee of Conference on the Personal Responsibility and Work Opportunity Reconciliation Act of 1996) ("Power and Flexibility to the States. The best welfare solutions come from those closest to the problems - not from bureaucrats in Washington. The legislation creates broad cash welfare and child care block grants providing maximum flexibility so that States can reform welfare in ways that are appropriate to them, and can move families into jobs."); See also H.R. REP. No. 104-651, at 1-6 (1996), reprinted in 1996 U.S.C.C.A.N. 2183, 2183-87 (describing the benefits of increased state flexibility, especially over waivers, because waivers "cannot substitute for fundamental, systemic changes that empower States and local communities to make their own decisions about how to address the needs of their populations. . . . Thus, welfare recipients are denied the full benefit of the innovations that States are seeking to initiate.").
} 
homage to the virtues of state flexibility, or even a competition to create the most flexible program. ${ }^{60}$ Then-Governor Tommy Thompson of Wisconsin testified before the House Committee on Government Reform that states did not use flexibility to race to the bottom, and that Congress should grant states even more flexibility in meeting Maintenance of Effort requirements and in other areas, such as health care and education. ${ }^{61}$ Representative Howard P. McKeon argued on the House floor in support of "super-waiver" authority under the Senate's reauthorization bill that increased flexibility will allow states "to better coordinate" welfare programs and "will encourage states to continue the experimentation at the state and local level that preceded the federal welfare reform action in 1996." ${ }^{, 2}$ Even the General Accounting Office, in its testimony before a House committee, couched its supportive statements in terms of neoTieboutian language of "state flexibility," experimentation, and interstate competition. ${ }^{63}$ The National Governors Association asserted its continued support for devolution of welfare because "[t]he TANF block grant has provided Governors the flexibility to implement innovative welfare reform programs based on work requirements and time limits, along with the ability to use TANF funds to provide needed work supports for low-income working families." ${ }^{64}$

\footnotetext{
${ }^{60}$ See generally 148 Cong. ReC. H2517 (May 16, 2002) (Debate on the Personal Responsibility, Work, and Family Promotion Act of 2002) (reflecting debate on whether welfare reform reauthorization proposals offer enough flexibility to the states).

${ }^{61}$ National Problems, Local Solutions: Federalism at Work. Part III, Welfare Reform is Working: A Report on State and Local Initiatives: Hearing Before the House Comm. on Gov't Reform, 106th Cong. 23 (1999) (statement of Tommy G. Thompson, Governor of Wisconsin).

62149 Cong. ReC. E188, E189 (daily ed. Feb. 11, 2003) (statement of Rep. McKeon).

${ }^{63}$ Implementation of Welfare Reform Work Requirements and Time Limits: Hearing Before the Subcomm. on Human Res. of the House Comm. on Ways and Means, 107th Cong. 6-69 (2002) (statement of Cynthia M. Fagnoni, Managing Director, Education, Workforce, and Income Security Issues of the General Accounting Office); U.S. GENERAL ACCOUNTING OfFICE, Welfare REForm: OUtCOMES For TANF RECIPIENTS With IMPAIRMENTS (July 2002), available at http://www.gao.gov/docsearch/date.php.

${ }^{64}$ National Governors Association, Policy Position HHS-21, Welfare Reform Policy 21.1 (formerly HR-36; effective Winter Meeting 2003-Winter Meeting 2005), at http://www.nga.org/nga/legislativeUpdate/1,1169,C_POLICY_POSITION^D_554,00.html.
} 
The NGA has argued for additional flexibility in a variety of areas when Congress reauthorizes the PRWORA. ${ }^{65}$

The opposition to welfare devolution is more muted in Congress, but, again, it is framed in neo-Tieboutian rhetoric. In arguing against unfettered devolution of Medicaid in 1995, Senator Graham used a neo-Tieboutian argument to support a proposal for a per capita cap approach to protect vulnerable Medicaid recipients from a race to the bottom in the Medicaid program. ${ }^{66}$ In commenting on welfare devolution in the wake of President Clinton's veto of earlier welfare reform legislation, Senator Moynihan made his position on welfare devolution via a blockgrant clear:

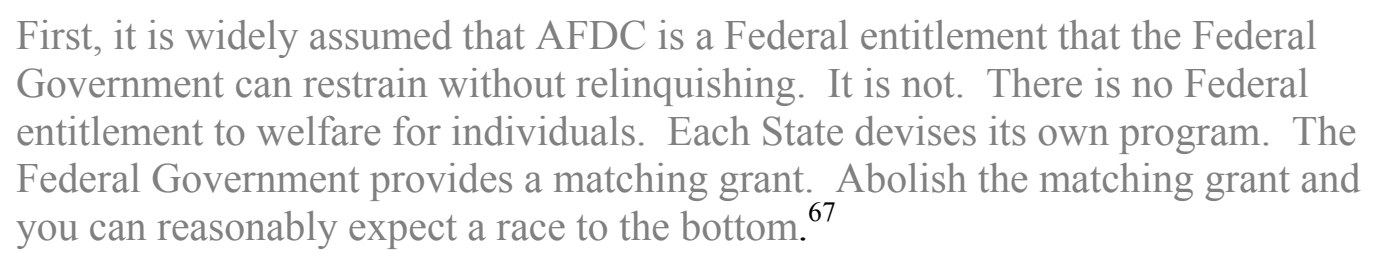

Thus, both sides of the debate about the form of federal-state relationships captured in the PRA framed their rhetoric around state experimentation and interstate competition, although they come down with very different conclusions. Supporters of the PRA argued that devolution would permit states to "experiment" to respond to local needs, desires, and conditions, and to compete with each other to provide an optimal level of benefits. And opponents of the PRA argued that devolution would result in a "race-to-the-bottom" among states, who would design welfare policies that would drive away their own poor and discourage opportunistic welfare migration from other states.

\footnotetext{
${ }^{65} \mathrm{Id}$. at 36.3 .

${ }^{66} 141$ Cong. ReC. S16845, S16847 (daily ed. Nov. 9, 1995) (statement of Sen. Graham) ("Per capita cap legislation is our way out of the race to the bottom and is our ticket to a $21^{\text {st }}$ century that maintains an American Federal-State stake in the health and welfare of its citizens.").

${ }^{67} 142$ Cong. REC. S115, S116 (daily ed. Jan. 10, 1996) (statement of Sen. Moynihan).
} 
This polarized debate about jurisdictional competition — and specifically about the mobility assumption, or opportunistic welfare migration - apparently led Congress to erect a kind of migration barrier in the PRWORA by permitting — but, notably, not requiring — states to provide immigrants from other states only the (lower) level of benefit that they would have received in their former state of residence for a period not to exceed 12 months. ${ }^{68}$ The purpose of this provision was to prevent opportunistic welfare migration ${ }^{69}$ while not running afoul of Shapiro v. Thompson. ${ }^{70}$

Several state legislatures, evidently concerned about opportunistic welfare migration as part of their enactments of relatively generous welfare packages under their welfare reform plans, ${ }^{71}$ took up proposals to erect the migration barrier permitted under $\S 604(\mathrm{c})$ as part of their new plans. ${ }^{72}$ Debates about these initiatives were consistently framed in the neo-Tieboutian rhetoric of state experimentation, interstate jurisdictional competition, and, specifically, opportunistic welfare migration. California provides a good, representative case study, because its migration barrier was in many ways archetypal and because it became the subject of Saenz v. Roe ${ }^{73}$ discussed below.

California's migration barrier read as follows:

\footnotetext{
6842 U.S.C. § 604(c) (2000) (stating that states "may apply to a family the rules (including benefit amounts) of the program funded under this part of another State if the family has moved to the State from the other State and has resided in the State for less than twelve months.").

${ }^{69}$ H.R. REP. No. 104-651, at 1339 (1996), reprinted in 1996 U.S.C.C.A.N. 2183, 2369.

70394 U.S. 618 (1969) (holding that state welfare statutes imposing a one-year residency requirement prior to awarding benefits under the AFDC program violate the Equal Protection Clause).

${ }^{71}$ Green v. Anderson, 811 F. Supp. 516, 520 n.14 (E.D. Cal. 1993) (citing and quoting legislative history of the California statute).

${ }^{72}$ Brief of the Commonwealth of Pennsylvania, et al, in Support of Petitioners at 14, Saenz v. Roe, 526 U.S. 489 (1999) (No. 98-97). Subsequently, in the wake of PRWORA, California implemented the provision. The courts again held it to be unconstitutional. Roe v. Anderson, 966 F. Supp. 977 (E.D. Cal. 1997), aff'd, 134 F.3d 1400 (9th Cir. 1998), aff'd sub nom. Saenz v. Roe, 526 U.S. 489 (1999).

At the time of the Saenz case, 12 states had adopted two-tiered residency requirements, and seven had been enjoined by the courts. Brief of the Commonwealth of Pennsylvania, et al, in Support of Petitioners at 14, Saenz v. Roe, 526 U.S. 489 (1999) (No. 98-97).

73526 U.S. 489 (1999).
} 
Notwithstanding the maximum aid payments specified in paragraph (1) of subdivision (a) of Section 11450, families that have resided in this state for less than 12 months shall be paid an amount calculated in accordance with paragraph (1) of subdivision (a) of Section 11450, not to exceed the maximum aid payment that would have been received by that family from the state of prior residence. ${ }^{74}$

California originally sought to implement this statute in 1992, before the enactment of the PRWORA, as a waiver under its AFDC program. ${ }^{75}$ Its implementation was enjoined, however, because it was held unconstitutional by a state court. ${ }^{76}$ The Supreme Court later vacated the case as non-ripe, because the waiver was under review in a separate case. ${ }^{77}$

In the wake of the PRWORA, however, California implemented this same provision. ${ }^{78}$ The rhetoric surrounding the original proposition and waiver request and later implementation was couched largely in language deriving from the mobility assumption. California's original waiver request justified its "relocation grant" program in terms of "reduc[ing] the incentive for families to migrate to California for the purpose of obtaining higher aid payments." ${ }^{, 79}$ The California Legislative Analyst Report on the proposal to create a "two-tier" system examined the research on opportunistic welfare migration (offering no solid conclusions for the California program), stating that

[t]wo-tier proposals have surfaced in other states; generally where the AFDC or [general assistance] grants are high compared to surrounding states. The concern driving these policy proposals is that people receiving assistance in low-benefit states are encouraged to move to high-benefit states in order to take advantage of

\footnotetext{
${ }^{74}$ CAL. Welf. \& Inst. Code, § 11450.03 (West 2001).

${ }^{75}$ Letter from Pete Wilson, Governor, California, to Jo Anne Barnhart, Assistant Secretary, U.S. Dep't of Heath and Human Services (May 19, 1992) (California’s Proposition 165 Waiver Request), in Joint Appendix 45-49, Saenz (No. 98-97).

${ }^{76}$ Green v. Anderson, 811 F. Supp. 516 (E.D. Cal. 1993), aff'd, 26 F.3d 95 (9th Cir. 1994).

77 Anderson v. Green, 513 U.S. 557 (1995) (holding that the appeal to the Supreme Court was not ripe, because, in parallel litigation, plaintiffs challenged the Secretary's approval of the waiver). The separate case is Beno v. Shalala, 30 F.3d 1057 (9th Cir. 1994).

${ }^{78}$ CAL. Welf. \& Inst. Code, $\$ 11450.03$ (West 2001).

${ }^{79}$ Letter from Pete Wilson, Governor, California, to Jo Anne Barnhart, Assistant Secretary, U.S. Dep't of Heath and Human Services (May 19, 1992) (California’s Proposition 165 Waiver Request), in Joint Appendix 45 \& 48, Saenz (No. 98-97).
} 
the higher benefit. In effect, the high-benefit state becomes a so-called 'welfare magnet.' Two-tier grants are thought to mitigate migration incentives. ${ }^{80}$

And members in the California Assembly floor debate-both pro-barrier and anti-barrier — used rhetoric derived from the mobility assumption, liberally to justify positions for and against the measure. $^{81}$

As mentioned above, these migration barrier measures were challenged at the United States Supreme Court in Saenz v. Roe. ${ }^{82}$ Although the legal issues in this case were framed in terms of right to travel, a consistent theme in the rhetoric of the parties, amici, and courts revolved around state experimentation and interstate jurisdictional competition, specifically around the mobility assumption. For example, in Saenz, the defendant's consistent and stated interest in adopting this policy was to deter opportunistic welfare migration. ${ }^{83}$ Amici also used opportunistic welfare migration as the basis for arguments for and against this provision. ${ }^{84}$ The

\footnotetext{
${ }^{80}$ Letter from Elizabeth G. Hill, Legislative Analyst, California Legislature, to Charles W. Quackenbush, Assembly Member, California Legislature (Dec. 19, 1991) (Legislative Analyst Report To Assemblymember Quackenbush), in Joint Appendix 51-52, Saenz (No. 98-97).

${ }^{81}$ California Assembly Floor Debate and Vote on SB 366 (Mar. 9, 1992), in Joint Appendix 63-74, Saenz (No. 98 97). For example, Mr. Costa said:

Realizing that in fact funds are short in California today, it makes a great deal of sense then to insure that incentives are provided for people from other parts of the country, in fact that who might be lured to California if in fact there is evidence to make that case, that people might be willing to come here for the purpose - to benefit from higher assistance. This legislation attempts to take care of that by requiring a one year residency requirement in California for anyone to benefit from the level of assistance that we now provide for people who are residents of California.
}

Id. at 63. On the other side of the debate, Mr. Bates argued: "[Immigrants from other states] are not coming here for any perceived welfare benefit increases that they somehow or other could get by coming to California. So we are deceiving ourselves if we think somehow or other people are coming to California for welfare benefits." Id. at 64.

82526 U.S. 489 (1999).

${ }^{83}$ Green v. Anderson, 811 F. Supp. 516, 522 n.14 (E.D. Cal. 1993) (citing and quoting legislative history of the California statute); Roe v. Anderson, 966 F. Supp. 977, 982-83 (E.D. Cal. 1997) (reviewing the parties' evidence on welfare migration and the "welfare magnet" hypothesis); Roe v. Anderson, 134 F.3d 1400, 1404 (9th Cir. 1998) ("At oral argument before this court, in response to the suggestion that the purpose of $\S 11450.03$ is to keep poor people out of the state, the state conceded that it does not want people to move to California 'with a mind-set of economic dependency." ").

${ }^{84}$ Brief of Social Scientists as Amici Curiae Supporting Respondents, Saenz (No. 98-97); Brief for William Cohen, et al., Amici Curiae, Supporting Respondents at 15-18, Saenz (No. 98-97); Brief for the United States as Amicus Curiae Supporting Petitioners in Part and Respondents in Part at 13-20, Saenz (No. 98-97) (discussing opportunistic welfare migration and the "welfare magnet" hypothesis, and arguing that 42 U.S.C. § 602(c) was enacted to help 
courts consistently held that this interest was insufficient and thus that the state statute was unconstitutional. $^{85}$

Similarly, in Maldonado v. Houstoun, ${ }^{86}$ the plaintiffs challenged a similar statute under Pennsylvania law. ${ }^{87}$ The plaintiffs argued that a primary purpose of enacting the law was to deter opportunistic welfare migration. ${ }^{88}$ The district court found that, while this was only a secondary purpose of the law, the statute was nevertheless unconstitutional. ${ }^{89}$ The circuit court, too, recognized that deterring opportunistic welfare migration was one purpose of the statute, and, in a summary statement, found that purpose "clearly unconstitutional.",90

mitigate the effects of opportunistic welfare migration); Brief of the Commonwealth of Pennsylvania, et al, in Support of Petitioners at 15-18, Saenz (No. 98-97).

${ }^{85}$ Green v. Anderson, 811 F. Supp. 516, 520, 521-22 (E.D. Cal. 1993) ("If the purpose of the measure is to deter migration by poor people into the State, and it appears that this may be the purpose, then the measure must be unconstitutional.") (footnote omitted); Saenz v. Roe, 526 U.S. 489, 506 (1999) ("These classifications may not be justified by a purpose to deter welfare applicants from migrating to California for three reasons."); Legislative Analyst Report to Assembly Quackenbush (Dec. 9, 1991) (in Saenz Joint Appendix to Supreme Court); California Assembly Floor Debate and Vote on SB 366 (March 9, 1992) (in Saenz Joint Appendix to Supreme Court);

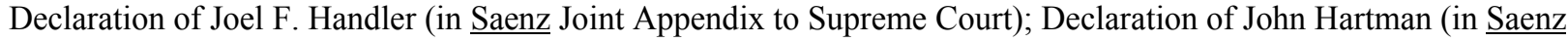
Joint Appendix to Supreme Court).

86177 F.R.D. 311 (E.D. Pa. 1997).

87 The Pennsylvania statute at issue, read: "Cash assistance for applicants and recipients of aid to families with dependent children who have resided in this Commonwealth for less than twelve months shall not exceed the lesser of the maximum assistance payment that would have been received from the applicant's or recipient's state of prior residence or the maximum assistance payment available to the applicant or recipient in this Commonwealth." 62 PA. Cons. Stat. AnN. § 432(5)(ii) (West 1996). In addition to $§ 432(5)(i i)$, there were other Pennsylvania statutes that similarly limited the welfare benefits that new Pennsylvania residents could receive. These other statutes imposed a waiting period on General Assistance benefits, 62 PA. CONS. STAT. ANN. $§ 432.4$ (West 1996), and denied Medical Assistance to residents who had lived in Pennsylvania less than 90 days. 62 PA. Cons. STAT. AnN. § 442.1(a)(1) (West 1996). The state Attorney General directed the state Department of Public Welfare not to enforce these statutes, finding that they were unconstitutional under prevailing United States Supreme Court precedent. Maldonado, 177 F.R.D. at 316 n.2.

88 Plaintiffs' argument rested on scant legislative history, see Maldonado, 177 F.R.D. at 329 n.22, and the testimony of Professor John Hartman. Id. at 328 n.20. Just as he testified in Saenz, Professor Hartman testified that there was no evidence to support the "welfare magnet" hypothesis. Id. The point here is not that plaintiffs' evidence or arguments were persuasive (or not), but that the rhetoric of the case- - from the parties to the evidence to the court's decision itself - revolved around jurisdictional competition and opportunistic welfare migration principles.

${ }^{89} \mathrm{Id}$. at 332 (finding that the state's purpose in deterring welfare migration - a secondary, not primary, purpose of the statute, according to the court — was unconstitutionally impermissible). The primary purpose of the statute- - to encourage employment, self-respect, and self-dependency among welfare recipients, according to the court—was not rationally related to the statute, and thus an unconstitutionally impermissible rationale, using rational-basis scrutiny. Id.

${ }^{90}$ Maldonado v. Houstoun, 157 F.3d 179, 189 (3d Cir. 1998) ("The district court found this purpose clearly unconstitutional under Shapiro and its progeny. We agree, and it does not warrant additional discussion.") The court went on to hold that the other stated purpose of the statute- "to encourage work and self-sufficiency over 


\section{Part III: Sorting Principles}

The neo-Tieboutian model, with its almost exclusive emphasis on the mobility assumption, leads to one of two polar conclusions: welfare ought to be (completely) devolved to the states to promote experimentation and responsiveness to local needs and desires or welfare ought to be (completely) federal to prevent "race-to-the-bottom" and "welfare magnet" effects. But these two positions clearly do not occupy the entire field of possibilities for welfare federalism - they are merely poles on a unidimensional continuum. To realize the full richness of federalism possibilities, we must diversify the debate and consider principles outside the narrow mobility assumption to help sort out the appropriate roles for the federal and state governments in the design and delivery of welfare programs.

This section thus seeks to introduce some candidates for diversified sorting principles in the devolution debate. The section considers two broad categories of sorting principles: those that are endogenous to Tiebout's original model; and those that are exogenous to the original model. The former category attempts to illustrate the paucity of considerations in the current debate even within the limited world of the Tiebout model. I attempt to show that the neoTiebotian debate, simply by considering other assumptions within the Tiebout model itself, could enrich the array of options for welfare federalism immeasurably. ${ }^{91}$

The latter category attempts to illustrate the even greater paucity of considerations in the current debate given the universe of options outside the Tiebout model. These exogenous sorting principles of political participation, community, and equality and justice seek to fill gaps in the narrow economic analysis of the Tiebout model and provide an even richer array of welfare

dependency" - was also unconstitutional, under a strict scrutiny test. Id. It is beyond the scope of this article to explore the appropriate level of scrutiny applied in "right to travel" cases; the point here is only that interstate jurisdictional competition language has become an entrenched part of the rhetoric.

${ }^{91}$ That they have not is curious. For example, why does the neo-Tieboutian debate focus almost exclusively on the mobility assumption, rather than some other assumption within the model, such as the knowledge assumption? 
federalism possibilities. The result is an exploration of potential factors to help sort out the complex and appropriate roles for federal and state governments in welfare.

This list, then, represents mere candidates for additional federalism sorting principles. This list is neither necessarily complete nor exhaustive; it simply represents potential additional considerations in the devolution debate. Moreover, my analysis of these principles does not necessarily point to any particular role for the federal or state governments, although it occasionally does. My intent here is not to provide specific answers, but only to raise questions. My modest hope is that these sorting principles will spawn new research, more diverse debate, and richer possibilities for welfare federalism.

\section{A. Endogenous Sorting Principles}

Considering that the devolution debate seems so deeply rooted in Tiebout's model and its neo-Tieboutian cousin, jurisdictional competition, it is surprising that the debate fails to consider Tiebout's knowledge assumption and externalities as sorting principles, alongside the mobility assumption. As discussed below, Tiebout himself seemed to argue that the knowledge assumption was as critical to his model as the mobility assumption. And consideration of externalities is a stand-by in federalism debates in other areas of public policy, most notably the environment. The knowledge assumption and externalities seem to be critical elements in a consideration of federalism under Tieboutian assumptions; this section attempts to sketch out the implications of including them as sorting principles for welfare federalism. Although I draw no specific conclusions, it is clear that including these considerations in the devolution debate results in a much richer array of possibilities for welfare federalism. This section also suggests that the mobility assumption should remain a principle — but merely one of several—in the devolution debate. 


\section{The Knowledge Assumption}

The omission of considerations relating to the knowledge assumption from the devolution debate is curious, considering that Tiebout himself seemed to place it on par with the mobility assumption. Tiebout wrote:

\section{Policies that promote residential mobility and increase the knowledge of} the consumer-voter will improve the allocation of government expenditures in the same sense that mobility among jobs and knowledge relevant to the location of industry and labor improve the allocation of private resources. ${ }^{92}$

The statement reflects a truism: citizens cannot make meaningful residential decisions based on a comparison of tax-benefit packages among jurisdictions without knowledge of those taxbenefit packages. Full knowledge is an important consideration in Tiebout's original model; it is also an important consideration in any jurisdictional competition or neo-Tieboutian model; it ought to be a consideration in the devolution debate.

The question from the government perspective in the devolution debate is: What level of government is best situated to provide information about welfare programs to citizens and potential citizens? Each individual state enjoys a comparative advantage in describing and publicizing its own program, and the states therefore may be in a good position to inform the citizenry within their own state and within other states. But if citizens really vote with their feet, as both sides of the devolution debate seem to assume, states' incentives to provide information about their programs depend on their desire to attract or repel citizens. For example, under neoTieboutian assumptions, states with relatively stingy programs have strong incentives to publicize their programs: they want to disseminate information about their programs within their boundaries to repel their own poor and outside their boundaries to discourage opportunistic welfare migration and to attract nonpoor citizens of other states. On the other hand, again under

\footnotetext{
92 Tiebout, supra note 14, at 423.
} 
neo-Tieboutian assumptions, states with relatively generous programs have a strong disincentive to publicize their programs, at least outside their own borders, in order not to encourage opportunistic welfare migration. Neo-Tieboutian assumptions may also encourage some states to publicize their programs inaccurately. Because states will always offer different welfare packages, there will always be incentives for states to variously publicize their programs: some will publicize more and accurately; others will publicize less and inaccurately. It seems therefore that there is a role for a central repository and publisher of information about various states' welfare programs; the federal government is well situated to play this role.

But there are other reasons, unrelated to jurisdictional competition, for governments to publicize their welfare programs. For example, publicity allows governments to better and more clearly articulate and reflect their community values. ${ }^{93}$ Publicity allows governments to share information about various program approaches and results. And publicity allows citizens to register their preferences through more traditional forms of democratic participation, such as voting and advocacy. ${ }^{94}$ These benefits to publicity may point in different directions with regard to welfare federalism; they ought to be a part of the devolution debate so that we can sort them out.

The question from the citizen and recipient perspective in the debate is: What level of government can best promote the capabilities among citizens and recipients to gain full information about welfare programs? The question implicates a host of democratic institutions - most notably public education — designed to promote and enable democratic and economic capabilities and functionings. It is well beyond the scope of this article to consider issues of federalism in institutions such as public education, but the existing location of these

\footnotetext{
${ }^{93}$ See infra.

${ }^{94}$ See infra.
} 
institutions in our federal system may help us better understand how to sort federal and state responsibilities in promoting knowledge of welfare programs.

It seems clear that knowledge and publicity are important considerations for welfare federalism, whether under neo-Tieboutian assumptions or not. The various reasons for knowledge and publicity may point us in different directions with regard to welfare federalism: some reasons may point toward state responsibility for publicity and the promotion of capabilities among citizens to understand the dimensions of welfare programs; others may point in the direction of federal responsibility. Still other considerations related to knowledge and publicity may demand an information analog to the federal migration barrier overruled in Saenz - something like a federal transparency requirement that might require states and local governments to collect and disseminate particular kinds of information about welfare programs for the purpose of educating the public. The point is merely that these considerations may yield a richer array of options for welfare federalism, and that they ought to be a part of the devolution debate.

\section{Externalities}

A second curious omission from the devolution debate relates to externalities.

Consideration of externalities is critical in any economic analysis of federalism, and externalities play a central role in federalism debates in other areas of public policy, most notably the environment. ${ }^{95}$ But the welfare devolution debate has been largely devoid of considerations of

\footnotetext{
${ }^{95}$ See, e.g., Henry N. Butler \& Jonathan R. Macey, Externalities and the Matching Principle: The Case for Reallocating Environmental Regulatory Authority, 14 YALE J. ON REG. 23 (1996); Symposium, The Role of Law in Defining Sustainable Development, 3 WIDENER L. SYMP. J. 1 (1998) (three articles on the topic "Externalities, Technology, and Sustainable Development"); Terence J. Centner, Concentrated Feeding Operations: An Examination of Current Regulations and Suggestions for Limiting Negative Externalities, 25 Colum. J. ENVTL. L. 219 (2000); Richard L. Revesz, The Control of Interstate Environmental Externalities in a Federal System, 38 ARIZ. L. REV. 883 (1996).
} 
externalities; as a result, the debate has failed to consider a critical element in sorting out federal and state responsibilities for welfare programs. Externalities ought to be a part of the debate.

Externalities in the welfare context are interstate economic effects of various state welfare programs and mobile welfare recipients. Under a devolved welfare scheme—and especially under a scheme like PRWORA, which emphasizes the economic functions of welfare through work requirements - economic effects of welfare programs and welfare recipients themselves may spill over between jurisdictions. In fact, under jurisdictional competition assumptions, we expect spill-over in the form of opportunistic welfare migration. As PRWORA takes root, we may observe other, even unanticipated forms of spill-over and externalities in economic harms and benefits between states. For a variety of reasons, states may lack the capabilities to internalize these spill-over effects, and, as some environmental scholars have argued, ${ }^{96}$ we may need to look to the federal government to cushion the impact of externalities between states.

The federal migration barrier at issue in Saenz seems an implicit recognition of this point: the migration barrier was designed to prevent prophylactically a spill-over in welfare recipients. ${ }^{97}$ Under Saenz, of course, there is no longer a federal prophylactic measure to deal with externalities. The devolution debate ought therefore to consider other, remedial and compensatory roles for the federal government in cushioning the effects of externalities between states.

\footnotetext{
${ }^{96}$ See Butler \& Macey, supra note 95, at 42 ("If nontrivial external costs are imposed across political boundaries, then the issue should be addressed by a higher level of government."); Paul S. Weiland, Federal and State Preemption of Environmental Law: A Critical Analysis, 24 HARV. ENVTL. L. REV. 237, 239 (2000) ("[C]entralization can overcome the problems associated with interjurisdictional negative externalities."); Daniel C. Esty, Revitalizing Environmental Federalism, 95 Mich. L. Rev. 570, 626 (1996) ("The presence of a transboundary harm demands some form of overarching governmental action across the scope of the harm.").

${ }^{97}$ See supra.
} 
It is unclear what role externalities play in devolved welfare programs, but it is clear that Congress was sufficiently concerned about one form of spill-over—opportunistic welfare migration - that it enacted a prophylactic measure to mitigate its effects. Having lost that tool to deal with spill-over in Saenz, Congress now ought to reconsider the role of externalities and their mitigation. More generally, the devolution debate ought to consider issues of externalities in welfare — what they are, how to measure them, and how to deal with them—in sorting out the appropriate division of responsibilities between the federal and state governments.

\section{The Mobility Assumption}

Finally, we ought to reconsider the mobility assumption in the devolution debate. Unfortunately — and despite the amount of discussion and research about it — the most we can say is that we do not really know whether opportunistic welfare migration exists or to what extent it impacts state welfare programs. ${ }^{98}$ The mobility assumption ought to remain a part of the debate, at least to the extent that we continue to examine how and why people migrate from state to state. But it ought to be merely one of several sorting principles- not the sole sorting principle—for welfare federalism.

Including the knowledge assumption and externalities alongside the mobility assumption as three endogenous sorting principles thus results in a more complex set of possibilities for welfare federalism. These endogenous considerations seem obvious considering their importance in Tiebout's original model; their inclusion here serves to illustrate the paucity of considerations in the current debate and to illustrate some of the possibilities for a richer

\footnotetext{
${ }^{98}$ See Schram, et al., supra note 46, at 227 ("[O]ur analysis provides a basis for questioning whether there are either significant causes or effects concerning welfare migration."); BRUECKNER, supra note 49, at 24 (concluding the evidence regarding welfare migration is mixed). Compare Scott W. Allard \& Sheldon Danziger, Welfare Magnets: Myth or Reality, 62 J. POL. 350, 363 (2000) ("[W]e find very little evidence to support the hypothesis that states with high welfare benefits retain a greater percentage of single-parent welfare receipients than states with lower benefits. We find more migration to lower-benefit states than to higher-benefit states."), with PETERSON \& ROM, supra note 46 , at $82-83$ (wefare migration exists).
} 
federalism. These points are underscored by considering candidates for exogenous sorting principles.

\section{B. Exogenous Sorting Principles}

The myopia of the current debate becomes even more acute if we consider sorting principles outside the Tiebout model. These principles - political participation, community, and equality and justice - are designed to include considerations beyond those merely economic in the devolution debate and thus fill clear gaps in the neo-Tieboutian assumptions and rhetoric. This section seeks to sketch out these three principles and some of the federalism implications that may flow from them.

\section{Political Participation}

One of the key problems with the neo-Tieboutian rhetoric is that it fails to account for the poor as civic actors and citizens in a democracy. The jurisdictional competition model contemplates that citizens, including the poor, register preferences exclusively via migrationthat citizens vote with their feet. It further assumes that governments respond to citizen preferences, as expressed exclusively through migratory patterns, by offering tax-benefit packages that attract an optimal level of citizens. In this marketplace for public goods, policy simply reflects the equilibrium tax-benefit packages that the government-sellers negotiate with the citizen-buyers. And the buyers' exclusive leverage in this negotiation is their power to walk away - to redirect their tax resources to a jurisdiction that better meets their tax-benefit preferences. Individuals in this model — and especially poor individuals, who lack the same, or perhaps any, leverage to walk away - are not full citizens, with all the attendant rights and duties in a democracy; instead, they are mere economic actors in a game of jurisdictional competition. 
The neo-Tieboutian rhetoric of the devolution debate strips individuals, particularly the poor, of their identity as diverse citizens and instead considers only their economic choices in the market for public goods as a proxy for their preferences for public goods. It does this by failing to account for the myriad alternative, non-economic ways of registering preferences in our democracy. For example, jurisdictional competition theory fails to account adequately for the roles of voting, participating, and aggregating preferences through interest group politics in registering preferences and shaping policy. Most simply, it assumes that if an individual resides within a jurisdiction, that individual's residence alone registers a preference for the tax-benefit package offered in the jurisdiction, even if the individual consistently votes against and advocates against the jurisdiction's policies. Rather than considering citizens as voters, active participants, or interest group members, jurisdictional competition theory treats individuals only as economic beings, ignoring the civic identities of citizens and the tools available to them to influence policy in a democracy.

Because the theory fails to account for individuals' civic identities, it also fails to account for civic differences. The theory fails to consider the many individual and group characteristics that contribute to civic inequality, e.g., race, gender, age, class, and geographic location, just to name a few. Instead, by neutralizing individuals' civic identities, the theory equalizes those identities: by holding civic identity constant and considering individuals only in an economic space, the theory holds not only that civic identity, but also civic difference, is irrelevant in predicting and fashioning policy. For example, the theory treats voting- and non-voting individuals in the same jurisdiction as each registering the same preference, irrespective of their votes and their civic inequality, solely by virtue of their residence within the jurisdiction. 
By failing to consider civic identity and civic inequality, the theory thus allows economic identity to crowd out civic identity, ${ }^{99}$ as if economic decisions in a jurisdictional competition world were a perfect proxy for preferences expressed through the more conventional channel of civic engagement. The simple examples above, and countless real-world experiences, illustrate that economic decisions are not such a close proxy, and the policy predictions in the jurisdictional competition model are therefore imperfect. Thus by failing to account for civic identity, jurisdictional competition theory can only predict, at best, a very imperfect equilibrium tax-benefit package for any jurisdiction, because it ignores other important civic factors that contribute to policy development.

Moreover, jurisdictional competition theory fails to account for economic inequalities. By ignoring inequalities, the theory seems to equalize individuals across classes, failing to account for the disparate impact on policy development among individuals or groups of different means. For example, the theory seems to predict that an individual of modest means registers his or her preferences via migration — and thus influences policy—as strongly as an individual of considerable means. This simply cannot be the case: under a pure economic model, such as the jurisdictional competition model, a relatively wealthy individual can always influence the market more than a relatively poor individual, because local jurisdictions benefit more from wealthy individuals. Jurisdictional competition fails to account for the different abilities to register preferences and influence policy that must result with market actors of different means; it thus fails to predict an accurate equilibrium tax-benefit package.

The failure of the theory to account for civic identities and civic and economic inequalities particularly skews the model on issues of redistribution to the poor. First, because

\footnotetext{
${ }^{99}$ As suggested here, the jurisdictional competition model also objectifies individuals as economic — not civic, social, or human-beings. This alone raises many interesting and troubling ethical issues, but they are beyond the scope of my narrow project in this article.
} 
the poor, by definition, lack resources and means, they are unable to register preferences in a jurisdictional competition world as strongly as others with means: migration of the poor in order to express a preference registers much lower than migration of the rich, because the poor are relatively less desirable and important to local jurisdictions. But the jurisdictional competition theory seems not to distinguish between poor and rich in predicting an equilibrium tax-benefit package based on individuals' migratory patterns. It thus overstates the influence of the poor in registering preferences and provides an imperfect predictor of policy.

Alternatively, we might consider the poor in their role as beneficiaries of public largess, not as taxpaying individuals. We encounter a similar limitation in the jurisdictional competition theory, but here it understates the influence of the poor. This alternative assumes that states treat the poor solely as a drag on the public fisc, not as preference-registering taxpayers. This ignores the jurisdictional competition methods that even the poor register preferences, for example, by paying sales taxes. The jurisdictional competition model thus understates the influence of the poor in registering preferences under this alternative. The point here, of course, is not to attempt to quantify the ability of the poor to register (or not) preferences as compared to the rich; rather, the point is simply to discuss the inherent mismatch between the jurisdictional competition predictions and actual policy as a result of the theory's failure to account for economic differences.

Next, by ignoring the ability of the poor to register preferences through political engagement, the jurisdictional competition model fails to predict their registration of preferences. Because the poor generally have a diminished ability to influence policy through civic engagement, the theory, by neutralizing and equalizing civic identity, tends to overstate the impact of the poor on policy development. By focusing exclusively on migration as the vehicle 
with which to express preferences, the theory assumes away any civic vehicle for expressing preferences. But these civic vehicles are likely to be employed relatively effectively by the nonpoor, and they are likely to be employed relatively ineffectively, if at all, by the poor. By equalizing the poor and the non-poor in civic space, jurisdictional competition overstates the impact of the poor on policy.

Consider, for example, the many public debates about welfare reform-including the devolution debate - and the conspicuous absence of voices in those debates of the poor. Welfare reform policy is shaped by academics, policy analysts, and primarily policy-makers, but certainly not the poor. The poor have a relative and profound disadvantage in registering policy preferences through political channels. By ignoring this reality—and by assuming that every individual has an equal opportunity to register preferences through (and only through) migration - jurisdictional competition theory tends to overstate the impact of the poor on policy. It therefore provides an imperfect model for predicting an equilibrium tax-benefit package. Jurisdictional competition theory thus reduces individuals to their economic beings and considers them only in an economic space. Because it ignores important differences in civic space that impact the development of policy, its predictions must be imperfect or subject to qualification.

The devolution debate, therefore, ought to include considerations of political participation. At a minimum, the debate should consider how the neo-Tieboutian predictions need to be adjusted to account for the political and civic ways in which all citizens register their preferences. For example, the debate should consider the following questions: How does the relative lack of political power of the poor distort the jurisdictional competition predictions? How does the relative political influence of the rich distort these predictions? At what levels of 
government do the poor and the rich have comparative advantages in registering their preferences via political engagement?

The answers to these and other, related questions will result in one of two situations. First, as is most likely, we may discover that jurisdictional competition overvalues the local political influence of the poor by ignoring political influence. In other words, by failing to account for relative differences in local political influence (and thus by equating political influence of the poor with influence of the rich), the model overstates the influence of the poor. By including political participation as a new variable in a grander model, the new model may thus predict an even greater desire among the states to cut welfare benefits - greater, that is, than states' desire under "race to the bottom." Absent some kind of local political equalizing mechanism - and in order to offset local political disparities - this new model may thus argue in favor of retaining greater federal control over levels of benefits, administrative access to benefits, requirements for the receipt of benefits, and other elements of benefits programs that states may tend to cut or restrict, given the even lesser ability of the poor to register preferences through conventional political channels.

Alternatively, as seems less likely, we may discover that jurisdictional competition undervalues local political participation among the poor and local (as opposed to national) support for public welfare programs. Perhaps citizens register a greater degree of support for these programs at the local level than the model predicts. If this is the case, the model may underestimate the degree to which states match citizen preferences for these programs, and "race to the bottom" rhetoric may be overstated, or at least imprecise. This result may argue in favor of policies that promote freer migration at the state and federal levels—or at least against migration barriers, notwithstanding the fact that the Court in Saenz found them 
unconstitutional—-because concerns about the drawbacks of free migration are overstated, and states well match citizen preferences.

Under either scenario, there are important policy implications given the adjustments to the neo-Tieboutian predictions based on a political analysis. The exact effects of the ability of the poor to register preferences through the political process are not clear ${ }^{100}$ more work needs to be done to tease out these issues — but it is clear that a neo-Tieboutian model fails to fully encompass the distorting effects of poverty on policy development. Political participation therefore ought to be a part of the devolution debate in order to help sort out the appropriate roles for federal and state governments in welfare programs.

\section{Community}

Community is another notably absent term in the lexicon of the devolution debate, and, in many ways, it is closely related to civic participation. The neo-Tieboutian debate thus ignores the poor as members of community. The idea of community in the context of welfare federalism asks: Through which level of government do we best reflect our community values relating to welfare? Is the expression of values relating to public welfare part of our national community identity? Or is it constituent of our state community identity? More simply: Which "we"- the national "we" or the state "we"- defines the relevant community for purposes of welfare programs? Are there particular and discrete aspects of welfare that are more closely associated with our national or state community identities ${ }^{101}$

\footnotetext{
${ }^{100}$ For a related analysis, see Sheryll D. Cashin, Federalism, Welfare Reform, and the Minority Poor: Accounting for the Tyranny of State Majorities, 99 Colum. L. REV. 552 (1999) (arguing for a framework of national standards in welfare to help insulate the disadvantaged poor from the "tyranny of the majority" in the states).

${ }^{101}$ Note that these questions do not assume a communitarian justification for welfare or attempt to justify welfare based on communitarian principles. See, e.g., Goodin, supra note 20 at 70-118 (arguing against a communitarian justification for welfare). Rather, they assume some justification for welfare (because it exists), and ask what levels of government-i.e., what communities - best comprise the values of welfare.
} 
Historically, welfare programs have accounted for questions of community: these programs have been designed to address particular community problems at the local community level or at the national community level or both. History thus provides some insights. For example, in the period of American history prior to the New Deal, welfare and poor relief were a matter of local concern. By the mid $19^{\text {th }}$ century, local communities had long provided "outdoor relief"- assistance to poor and destitute people in their homes. In addition, some poor were auctioned to local farmers, and others — strangers to the local community — were expelled from the town. By 1850 , specialized residential institutions began to spring up in local communities. These were designed to cut off the poor from corrupting influences that led to their poverty in the first place, to rehabilitate the poor by transforming behavior and personalities, and to inculcate habits and ethics of work. ${ }^{102}$

These earlier forms of welfare thus located their nuclei in the local community. This made some sense from a communitarian perspective: given the close identification and affiliation that citizens at the time had with their more local spheres of community, local control over welfare programs would seem to best reflect and promote the values of citizens' primary communities. Local communities were the primary site of citizens' economic, civic, and social activities, ${ }^{103}$ and local communities exhibited a relatively greater level of cohesion and stickiness for both poor and non-poor citizens. ${ }^{104}$ Individuals associated with their local communities and the local poor mostly associated with the national community or the poor in distant communities. Their reaction to poverty on a local level was a reflection of their local community values

\footnotetext{
102 Michael B. Katz, In the Shadow of the Poorhouse: A Social History of Welfare in America 1-11 (10th Anniversary ed. 1996).

${ }^{103}$ NEED CITE

${ }^{104}$ NEED CITE
} 
(whatever we think about those values today). Because poverty was a local problem, local community solutions would best reflect the relevant local community values.

The post-New Deal welfare programs, in contrast, located their nuclei in the national community. This also made some sense: poverty was increasingly becoming a nationalized issue, and the national community was best situated to address it. The increasingly nationalized causes of poverty—e.g., the Great Depression and other nationalized causes of economic fluctuations and poverty—-demanded a response by the federal community. ${ }^{105}$ Moreover, increased intra-state migration and increased channels of intra-state communications resulted in a relative rise in the importance of broader spheres of community, ${ }^{106}$ outside the more pedestrian local communities. And a $20^{\text {th }}$ century marked by major events of a national, not state or local, scale helped create a broader federal community in which national values and sentiments trumped state and local values and sentiments, especially in economic and security matters. ${ }^{107}$ Poverty thus became a relatively national problem within the national community.

The nationalized nature of poverty that gave rise to post-New Deal welfare programs has not dissipated. And our national community sentiments, especially as they relate to economic matters, have only increased in the late $20^{\text {th }}$ and early $21^{\text {st }}$ centuries. Poverty and welfare are issues of concern for our national community. At the same time, local communities remain deeply involved in issues related to poverty and welfare, and local community sentiments ought to be accounted for.

In addition to considering these positive historical trends about community and welfare, we ought to also deal with the normative questions about the kinds of communities we wish to form on the national, state, and local levels. For example, do we wish support for our poor to be

\footnotetext{
105 See KATZ, supra note 102, at 220-31.

${ }^{106}$ NEED CITE

${ }^{107}$ NEED CITE
} 
a part of our national community identity? Should it be limited to the identities of state and local communities? Or perhaps we seek some more sophisticated balance that permits support to be constituent of each community. There are, of course, scores of related questions and issues. My purpose here is not to delineate them and certainly not to answer them. Rather, I mean only to suggest that these questions and issues ought to be a part of the devolution debate.

\section{Equality and Justice}

Finally, questions of equality and justice are present in the devolution debate only by virtue of their presence in the broader, substantive debates about welfare reform. For example, the issue of federal entitlement has been an important part of the broader welfare reform debate. The federal entitlement protected some measure of equality and justice by ensuring certain federal standards in welfare programs across states and local jurisdictions. But the narrower devolution debate is rarely couched in terms of entitlement, federal or state. Here, I do not intend to focus narrowly on issues related to entitlement; instead I intend to raise questions of equality and justice as they relate to larger questions about the appropriate levels of government to preserve these principles, through entitlement or otherwise. These questions are, of course, closely related to issues of community, as part of the questions ask: Which communitiesfederal, state, or local—value which kinds of equality and which kinds of justice?

Begin with the less controversial issue of equality: What level of government best preserves equality across state and local jurisdictions in the allocation and administration of welfare programs? Consider two welfare recipients in different state or local jurisdictions and subject to different welfare benefits and administrative schemes. Under a devolved system, one recipient might receive lower benefits, be subject to higher or more onerous requirements, and be subject to greater administrative barriers than the other recipient from a different jurisdiction. 
We might observe differences like this even under a system of "adjusted equality" that accounts for legitimate variances in local conditions, such as differences in local costs of living. Prodevolutionists claim that such disparate treatment is a reflection of local considerations, while anti-devolutionists claim that it is evidence of a "race to the bottom." But neither side seems to consider the differences in the context of federalism: Which level of government is best suited to define and preserve equality, or adjusted equality, across jurisdictions? ${ }^{108}$

If equality is an important consideration at the state level of government or communityi.e., equality across welfare programs within the state — perhaps states are best suited to define and preserve equality within their borders (for they have no direct control over programs outside their borders). Inequality may arise within states that practice "double devolution," or further devolution of welfare program functions downward away from the state government and toward local governments, thus creating an environment where inequalities across local jurisdictions within a state are possible or even likely. Equality minded states may seek to equalize benefit levels, program requirements, and administrative burdens across local jurisdictions based on some formula that accounts for local costs of living, local economic conditions, and the like. In fact, states, as entities closest to the local governments and the local situations, may have a comparative advantage over the federal government in acting as the equalizing force. But under a block-grant form of federalism that caps federal funding and penalizes states for failing to meet standards such as work participation rates, states lack financial incentives to promote equality. Moreover, as the entities closest to the local governments and local situations, states may be

\footnotetext{
${ }^{108}$ I use here a simple and relatively non-controversial definition of equality, adjusted for local situations: Similarly situated individuals ought not to be treated significantly differently in welfare programs, after accounting for local variations in such things as cost of living, local economies, and the like. Of course, this leaves much open to debate. But that is exactly the point: these issues ought to be a part of the debate.
} 
more receptive to political considerations that actually promote inequality. Thus, the federal government may have a comparative advantage as the equalizing force in these situations.

If equality is an important consideration at the federal level-i.e., equality in programs across states - the federal government clearly has a comparative advantage in defining and preserving it. Consider a state that underfunds its welfare program or imposes harsher requirements relative to programs in other states, thus raising equality issues across states. The relatively stingier state has no financial incentive to increase funding under a block-grant devolution system, and it has no direct control over the programs in other states. Neither can other states directly impact the behavior of the stingier state; only the federal government can provide the incentives to promote equality.

Consider alternatively a state that overfunds its welfare program or relaxes its requirements relative to programs in other states. Presumably, a relatively generous state behaves thus for a reason—community values, historical norms, or economic or political considerations unique to that state - and these considerations outweigh the financial benefit to the state in providing less generous programs. Given this calculation, the relatively generous state is unlikely to reduce benefits out of equality concerns for recipients in other states. And less generous states have no incentive to increase their own benefits to promote equality with the generous state. No state can directly impact the behavior of any other state to promote equality; again, only the federal government can provide incentives to promote equality between states.

States, by their nature, lack the capabilities of dealing with these equality issues in welfare programs within and across states; the federal government seems to have a comparative advantage in this arena. But I do not mean to imply that states ought not to play a role in defining and promoting equality within states or among states. I mean only to suggest that 
equality definitions and standards ought to be considerations in the devolution debate to allow that debate to sort these considerations out.

Next consider the more controversial issue of justice, defined more generally than equality: What level of government is best situated to define and promote standards of justice and fairness in welfare programs? Consider first procedural justice, or fairness as it relates to the process of applying for and receiving benefits. Certainly a component of procedural justice is relative fairness, or equality, discussed above in general terms. But another component of procedural justice is objective fairness of process, i.e., a fair process for any recipient, or a bare minimum standard, irrespective of equality considerations. ${ }^{109}$ Because welfare programs at issue in this paper, devolved or not, are generally jointly funded by the federal and state governments, it seems reasonable that both federal and state governments would assert an interest in objective procedural fairness and that both levels of government ought therefore to establish and enforce such standards.

Consider next substantive justice, or fairness in the benefit level and program requirements such as work requirements. Like procedural justice, substantive justice contains an element of relative fairness, or equality, discussed above in general terms. But it also contains an element of objective fairness in the level of benefits, i.e., an objectively fair level of benefits (a bare minimum) and fair requirements (maxima, perhaps), irrespective of equality. States may enjoy a comparative advantage in determining these standards by virtue of their specialized knowledge of local conditions, but the federal government may also assert an interest by virtue of its desire to reflect federal community standards in its welfare programs.

At bottom, considerations of equality and justice may point in various, even contradictory, directions. But the absence of considerations of equality and justice in the ${ }^{109}$ See generally Goldberg v. Kelly, 397 U.S. 254 (1970). 
devolution debate has resulted in a paucity of options for welfare federalism. (Re)introducing these concepts into the debate will result in a wider, more diverse range of federalism options as policymakers continue to consider devolution in welfare programs.

\section{Conclusion}

The two sides in the current welfare devolution debate seem to argue inexorably toward two polar positions of complete federal control on the one side versus complete devolution on the other. In support of these positions, the sides rely on a rhetoric that seems almost intuitively narrow: the anti-devolutionists argue against devolution based on "race-to-the-bottom" and "welfare magnet" predictions; the pro-devolutionists argue for devolution based on “experimentation," "responsiveness to local needs and desires," and even "race-to-the-top" theories. We may trace the intellectual roots of these arguments to a single assumption - the mobility assumption — in Charles Tiebout's famous 1956 article, A Pure Theory of Local Expenditures and thus reveal the paucity of considerations or principles that feed the debate.

By expanding the debate beyond the sole principle of Tiebout's mobility assumption, we gain an appreciation for the rich possibilities in welfare federalism that are lost in the current debate. By looking beyond mobility, we may discover additional principles that help sort out the complex and appropriate roles for the federal and state governments in the design and implementation of welfare programs. 